\title{
Variations of anterior and posterior division of internal iliac artery: A systematic review and clinical implications
}

\author{
Hadis Mohammadbaigi ${ }^{1}$, Marzieh Darvishi ${ }^{1,2,{ }^{*}}$, Ardeshir Moayeri ${ }^{1,2}$
}

${ }^{1}$ Department of Anatomy, Faculty of Medicine, Ilam University of Medical Sciences, Ilam, Iran

${ }^{2}$ Student research committee, Ilam University of Medical Sciences, Ilam, Iran

\section{Correspondence}

Marzieh Darvishi, Department of Anatomy, Faculty of Medicine, Ilam University of Medical Sciences, llam, Iran

Student research committee, llam University of Medical Sciences, Ilam, Iran

Email: Darvish-m@medilam.ac.ir

\section{History}

- Received: Feb 28, 2019

- Accepted: Apr 27, 2019

- Published: May 31, 2019

DOI :

https://doi.org/10.15419/bmrat.v6i5.546

\section{Check for updates}

\section{Copyright}

(c) Biomedpress. This is an openaccess article distributed under the terms of the Creative Commons Attribution 4.0 International license.

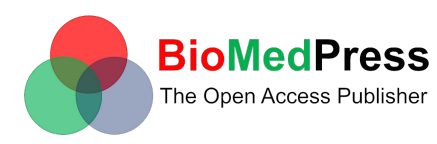

\begin{abstract}
The distribution pattern of internal iliac artery (IIA) implies its bifurcation to two branches, the anterior and the posterior trunks. According to previous research, IIA indicates several anatomical variations. The purpose of this study is to evaluate the types of these variations. The presence of these variations in the arteries is an important topic to urologists, gynecologists, radiologists, and general surgeons because they can be ruptured during surgical procedures in the perineal and pelvis region. Three databases were searched for the period from 1810 to January 2018 and a total of 75 studies were investigated. This study evaluated the branching of the internal iliac artery in several literatures and compared it with Adachi's classification. This finding can lead to improve surgical technique and safety in medical practice.

Key words: Internal iliac artery, Pelvic vascularization, Umbilical artery, classification, distribution pattern
\end{abstract}

\section{INTRODUCTION}

From an anatomic point of view, internal iliac artery (IIA) begins as a terminal branch of the common iliac artery at the level of sacroiliac joint. Each IIA is around $3.5 \mathrm{~cm}$ long, descending near the upper border of greater sciatic foramen and divides into anterior and posterior branches. The ureter, uterine tube and ovary are placed on the anterior surface of the IIA. However, the internal iliac vein and lumbosacral trunk pass from the posterior side of IIA. The branches arising from the anterior and posterior trunks of the IIA are described in Table 1. Anterior trunk distributes to the pelvic viscera and posterior trunk supplies to the body wall and buttocks ${ }^{1-3}$. During development, this artery derives from the proximal part of umbilical artery that is also called hypogastric artery whereas the distal part of umbilical artery obliterated postnatally ${ }^{2,4}$. This embryological development leads to several variations in the origin of IIA and its branching pattern into two major trunks ${ }^{3}$. Hence, understanding anatomical variation of IIA is essential for surgeons to apply the IIA ligature to prevent hemorrhages following by pelvic surgeries, hysterectomies and orthopedic surgeries related to hip joint. Previous studies show that the level of origin of IIA is variable and dependent on the length of the common iliac artery and the level of division of IIA ${ }^{5}$. Typically, the origin of the IIA is between L5 and the upper border of $S 1^{1,2}$. When we searched for the anomalies declared on the normal pattern, IIA shows several anatomical variations. There have been studies that describe different forms of IIA in a population or individually. However, we attempted to create a proper classification of these variations, since each author described his own findings as an independent classification. Hence, none of the categories represent the observed variations completely. In this study, we collected recent reports to:

1. Investigate the variations of anterior division of the IIA.

2. Examine the variations of posterior division of the IIA.

3. Update the IIA classification based on recorded data.

The first attempt to classify variant patterns of IIA was performed by Jastschinski that showed four types which he described on an investigation of variant patterns of IIA branches. This classification was based on the four branches that included the inferior gluteal artery, internal pudendal artery, superior gluteal artery and umbilical artery ${ }^{6}$.

\section{MATERIALS AND METHODS}

\section{Research method}

The report of this review study was based on a systematic review and meta-analysis (PRISMA) (7). PUBMED, ISI web of knowledge and SCOPUS were 


\begin{tabular}{|c|c|c|c|}
\hline Branches of IIA & & Male & Female \\
\hline \multirow[t]{8}{*}{ Anterior trunk of the IIA } & Parietal branches & Internal pudendal artery & internal pudendal artery \\
\hline & & Inferior gluteal artery & inferior gluteal artery \\
\hline & & Obturator artery & Obturator artery \\
\hline & Visceral branches & Umbilical artery & Umbilical artery \\
\hline & & Superior vesical artery & superior vesical artery \\
\hline & & $\begin{array}{l}\text { Inferior vesical artery } \\
\text { middle rectal artery }\end{array}$ & $\begin{array}{l}\text { Vaginal artery (replaced by inferior } \\
\text { vesical artery) }\end{array}$ \\
\hline & & & middle rectal artery \\
\hline & & & uterine artery (only in women) \\
\hline \multirow[t]{3}{*}{ Posterior trunk of the IIA } & Parietal branches & Superior gluteal artery & Superior gluteal artery \\
\hline & & lateral sacral arteries & lateral sacral arteries \\
\hline & & Iliolumbar artery & Iliolumbar artery \\
\hline
\end{tabular}

searched for published studies up to January 2018. Three anatomical textbooks (Gray's Anatomy, SNELL and Netter) were evaluated in order to find any type of evidence in association with IIA. Several key words were used in our search, including "internal iliac artery", "hypogastric artery", "arteria iliaca interna", "anterior division internal iliac artery" and "posterior division internal iliac artery". To increase the accuracy of the process, two independent researchers carried out writing the papers and evaluating data. The study was evaluated and selected in three stages. In the first step, citation information and a summary of the evaluated papers were transferred to the Endnote software. Then the titles of the selected articles were reviewed and the articles that were not related to the main topic of the research were excluded. In the second stage, from the abstracts, articles related to the main subject were determined. Finally, the original text of the selected articles was assessed.

\section{Inclusion and exclusion criteria}

The data included into the study complied with the following criteria:

1) they were consisted of original research, case report and review articles from the anatomical variations of the AII in cadaveric, clinical and imaging sample studies, or those which provided data about variation of the superior vesical artery (SVA), inferior vesical artery (IVA), middle rectal artery (MRA), obturator artery (OA), internal pudendal artery (IPA), inferior gluteal artery (IGA), uterine artery (UtA), vaginal artery (VA), superior gluteal artery (SGA), lateral sacral arteries (LSA) and iliolumbar artery (ILA).
2) Only human studies were selected.

3) There were no restrictions related to the demographic characteristics of the sample study (race, sex, and age).

\section{Study selection and data extraction}

The initial electronic and manual search yielded 4398 articles. After extracting all papers, evaluating the titles and removing double and irrelevant articles, 1184 studies were selected. After reviewing the abstracts and their adaptation to the inclusion and exclusion criteria, 204 articles related to the subject matter remained. After evaluating the full texts of the articles, 129 articles were disqualified and 75 articles were confirmed and prepared for final analysis. The process of extracting and selecting articles is shown in Figure 1. The required data included the origin of IIA at different levels, distance from greater sciatic foramen and types of IIA, SVA, IVA, MRA, OA, IPA, IGA, UtA, VA, SGA, LSA, ILA, variations (first author's name, publication year, sample size and mean).

\section{RESULTS AND DISCUSSION}

\section{Distribution of the internal iliac artery (IIA)}

According to the older terminology, IIA arises from the common iliac artery at the level of the sacroiliac joint and adjusts with the intervertebral disc between L5 and S1, then descends posteriorly within the pelvic cavity; subsequently, it reaches the greater sciatic foramen ${ }^{1-4}$. Several studies reported the variation in the origin of the IIA (Table 2). The findings of previous studies indicate that the most common anatomical position of the origin of the internal iliac artery is 
Extract articles based onkeywords and electronic search strategies $(n=4382)$
Records after manual searching

$$
\text { (n=16) }
$$

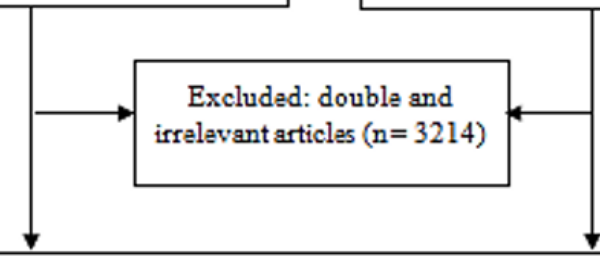

Records after evaluation of title ( $n=1184)$

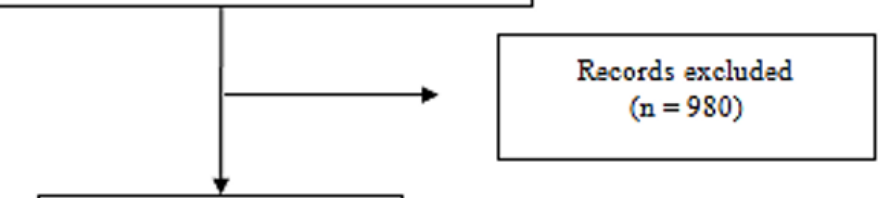

Records after evaluation of abstract ( $n=204$ )

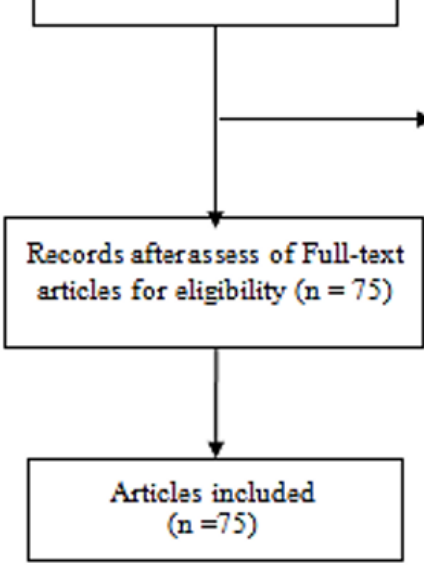

Full-text articles excluded ( $n=129$ ) based on:

- Un-extractable data

- Non-human

- Ineligible population

- Repeat of data in several articles

- Patency, aneurysmand other trauma

Figure 1: PRISMA diagram of included articles into process.

Table 2: Origin of internal iliac artery (IIA) at different levels

\begin{tabular}{lllll}
\hline Study & Ref & Vertebral level & No. of specimen & Percentage \\
Mamatha (2015) & 5 & L5-S1 vertebra & 36 & $72^{*}$ \\
& & S1 vertebra & 12 & 24 \\
& & L5 vertebra & 2 & 4 \\
Sakthivelavan (2014) & 6 & L5-S1 vertebra & 94 & $81^{*}$ \\
& & Above level & 22 & 19 \\
Havaldar (2014) & 7,8 & L5-L4 vertebra & 8 & 16 \\
& & L5-S1 vertebra & 30 & $60^{*}$ \\
& & L5 vertebra & 10 & 20 \\
Naveen (2011) & & S1 vertebra & 2 & 4 \\
Fatu (2006) & & S1 vertebra & 35 & $58.3^{*}$ \\
& & L5-S1 vertebra & 24 & 40 \\
& & L5 vertebra & 1 & 1.7 \\
\hline
\end{tabular}




\begin{tabular}{|c|c|c|c|c|}
\hline Study & Ref & Distance & No. of specimen & Percentage \\
\hline \multirow{5}{*}{$\begin{array}{l}\text { Mamatha H etal. } \\
\text { (2015) }\end{array}$} & \multirow[t]{5}{*}{5} & Above $2 \mathrm{~cm}$ & 14 & 28 \\
\hline & & Above $2.5 \mathrm{~cm}$ & 18 & $36^{*}$ \\
\hline & & Above $3 \mathrm{~cm}$ & 9 & 18 \\
\hline & & Above $3.5 \mathrm{~cm}$ & 8 & 16 \\
\hline & & Below $1 \mathrm{~cm}$ & 1 & 2 \\
\hline \multirow{10}{*}{$\begin{array}{l}\text { Havaldar } \quad P \quad \text { etal. } \\
(2014)\end{array}$} & \multirow[t]{10}{*}{8} & Above $0.5 \mathrm{~cm}$ & 9 & $18^{*}$ \\
\hline & & Above $1 \mathrm{~cm}$ & 9 & $18^{*}$ \\
\hline & & Above $1.5 \mathrm{~cm}$ & 4 & 8 \\
\hline & & Above $2 \mathrm{~cm}$ & 9 & $18^{*}$ \\
\hline & & Above $2.5 \mathrm{~cm}$ & 2 & 4 \\
\hline & & Above $3 \mathrm{~cm}$ & 1 & 2 \\
\hline & & At Upper border & 7 & 14 \\
\hline & & below the upper border 0.5 & 4 & 8 \\
\hline & & below the upper border $1 \mathrm{~cm}$ & 3 & 6 \\
\hline & & below the upper border $2 \mathrm{~cm}$ & 2 & 4 \\
\hline \multirow{3}{*}{$\begin{array}{l}\text { Havaldar } \quad P \quad \text { etal. } \\
(2014)\end{array}$} & \multirow[t]{3}{*}{11} & Above & 34 & $68^{*}$ \\
\hline & & Upper border & 7 & 14 \\
\hline & & below the upper border & 9 & 18 \\
\hline \multirow{2}{*}{$\begin{array}{l}\text { Sakthivelavan S etal. } \\
\text { (2014) }\end{array}$} & \multirow[t]{2}{*}{6} & Upper border & 79 & $65.5^{*}$ \\
\hline & & $\begin{array}{l}\text { position between lumbosacral ar- } \\
\text { ticulation and greater sciatic notch }\end{array}$ & 40 & 34.5 \\
\hline \multirow[t]{6}{*}{ Naveen et al (2011) } & \multirow[t]{6}{*}{9} & Above $3 \mathrm{~cm}$ & 18 & $30.7^{*}$ \\
\hline & & Above $2 \mathrm{~cm}$ & 14 & 23.1 \\
\hline & & Above $2.5 \mathrm{~cm}$ & 12 & 19.8 \\
\hline & & Above $4 \mathrm{~cm}$ & 8 & 13.2 \\
\hline & & Above $3.5 \mathrm{~cm}$ & 4 & 6.6 \\
\hline & & Above $5.5 \mathrm{~cm}$ & 4 & 6.6 \\
\hline
\end{tabular}

at the level of lumbosacral (L5-S1).

The IIA divides at the level of superior edge of greater sciatic notch. Table 3 shows variations in IIA division in the vicinity of the greater sciatic foramen.

In 1928, this classification was introduced by Adachi in Japanese subjects with a slight change ${ }^{12}$. He described IIA variations in five types which include:

Type I: The superior gluteal artery and a common trunk arise from IIA. The common trunk is bifurcate and forms the inferior gluteal and internal pudendal arteries. If the common trunk divides into the pelvis, it is type Ia, and if it is outside the pelvis then it's classified as type Ib.

Type II: The internal pudendal artery and a common trunk arise from IIA. The common trunk is bifurcate and forms the inferior gluteal and superior gluteal arteries. If the common trunk divides into the pelvis, it is of the type IIa, and if it is outside the pelvis then it is classified as type IIb.

Type III: The internal pudendal artery and two gluteal arteries are given off separately from the internal iliac artery.
Type IV: The internal pudendal artery and two gluteal arteries originate from the same trunk. In type IVa, the trunk first gives rise to the superior gluteal artery while in type IVb, the internal pudendal is the first vessel to be separated.

Type V: The inferior gluteal artery and the common trunk arise from IIA. The common trunk is bifurcate and forms the internal pudendal and superior gluteal arteries into the pelvis (Figure 2).

\section{Anterior trunk of the IIA}

\section{Parietal branches}

\section{Internal pudendal artery (IPA)}

The most common origins of the internal pudendal artery (IPA) are a branch that stems from the anterior division of the IIA and is the main vessel of the perineum. However, several articles confirm the variable source for this artery. It is important for anatomists and surgeons to understand of IPA ${ }^{1-4}$. The IPA was classified by Kawanishi ${ }^{29}$ in the vicinity of the greater 

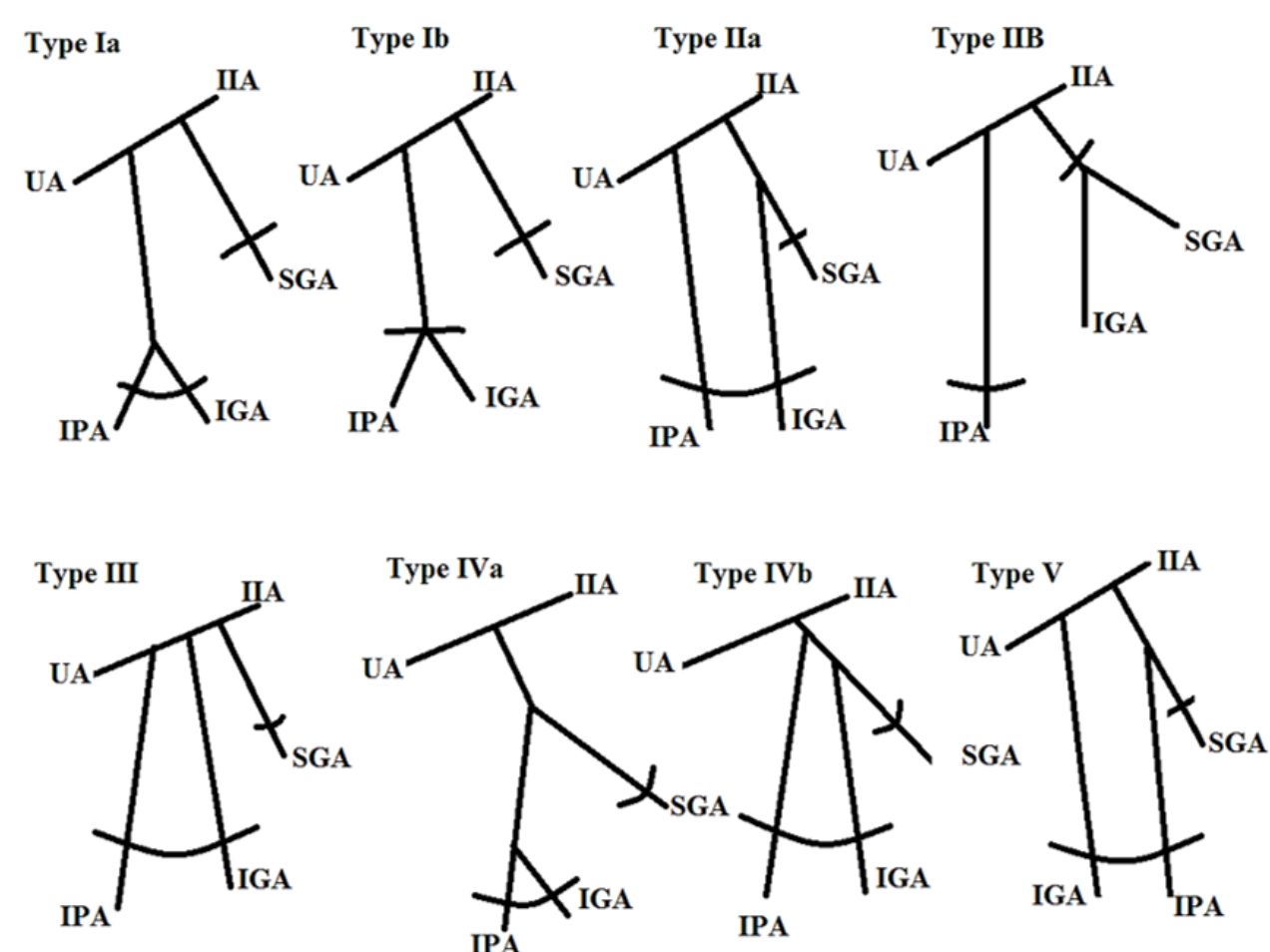

Figure 2: Adachi's types of IIA variations. IIA: internal iliac artery; IGA: Inferiorgluteal artery; IPA: Internal pudendal artery; SGA: Superior gluteal artery; UA:Umbilical artery ${ }^{12}$.

sciatic notch, the linea terminalis, and the ischial spine

(Tables 5 and 4).

Inferior gluteal artery (IGA)

The IGA is the larger terminal branch of the anterior division of IIA and supplies the buttock and thigh. It descends anteriorly to the piriformis muscle and posterior to the IPA ${ }^{1}$. It passes between the piriformis and ischiococcygeus muscle. Then IGA runs through the greater sciatic notch to reach the gluteal region. Gabrielli (1997) showed that the IGA branches penetrated the sciatic nerve in $22.5 \%$ of cases $^{30}$. The IGA and IPA arteries often originate as a common stem from the IIA, sometimes with the SGA (Table 6).

\section{Obturator artery $(\mathrm{OA})$}

One anther of the branches of the anterior trunk of the IIA is obturator artery (OA). This artery passes through the external walls of the pelvis and the artery reaches obturator foramen and enters the obturator canal. In this way it is divided into the vesical, pubic and acetabular branches also, OA supplies the medial compartment of the thigh ${ }^{1,3}$. In order to prevent vascular injury and hemorrhage during surgery of the
Bogros space and mesh stapling in inguinal or obturator hernia surgery, it is necessary to identify the variations of $\mathrm{OA}$ and their distance and orientation to the femoral ring ${ }^{39}$. Several papers presented the aberrant of OA in a cross from the pelvic (Table 6). 
Table 4: Types of IIA variations according to Adachi classification (\%)

\begin{tabular}{|c|c|c|c|c|c|c|c|c|}
\hline \multirow[t]{2}{*}{ Study } & \multirow[t]{2}{*}{ Year } & \multicolumn{6}{|c|}{ Types of IIA variations according to Adachi classification\% } & \multirow[t]{2}{*}{ No. of } \\
\hline & & I & II & III & IV & $\mathbf{V}$ & Other & \\
\hline Lipshutz $^{13}$ & 1916 & 51 & 24 & 17 & 7 & - & - & 181 \\
\hline Adachi $^{12}$ & 1928 & 51.2 & 23.1 & 18.2 & 4.1 & 0.8 & 2.5 & 121 \\
\hline Tsukamoto $^{14}$ & 1929 & 56.5 & 8.4 & 22 & 12.9 & - & - & 287 \\
\hline Miyaji ${ }^{15}$ & 1935 & 70.4 & 11.7 & 9.5 & 8.4 & - & - & 179 \\
\hline Aria $^{16}$ & 1936 & 52.4 & 19.4 & 24 & 4.2 & - & - & 500 \\
\hline Hoshiai ${ }^{17}$ & 1938 & 55.1 & 16.1 & 26.1 & 2.6 & - & - & 379 \\
\hline $\begin{array}{l}\text { Ashley \& } \\
\text { Anson }^{18}\end{array}$ & 1941 & 58.1 & 17.3 & 9.6 & 7.7 & - & 7.3 & 260 \\
\hline Suzuki ${ }^{19}$ & 1951 & 53.2 & 18.8 & 24.1 & 3.7 & 0.2 & - & 490 \\
\hline Braithwaite $^{20}$ & 1952 & 58.5 & 15.3 & 22.5 & 3.6 & - & - & 169 \\
\hline Yasukawa ${ }^{21}$ & 1954 & 53.7 & 18.4 & 23.9 & 4 & - & - & 544 \\
\hline Fischer ${ }^{22}$ & 1959 & 50 & 26 & 16 & 8 & - & - & 50 \\
\hline $\begin{array}{l}\text { Roberts } \\
\& \quad \text { Krish- } \\
\text { ingner }^{23}\end{array}$ & 1968 & 50.9 & 27 & 14.4 & 7.2 & - & 0.6 & 167 \\
\hline Morita $^{24}$ & 1974 & 49.1 & 22.5 & 21.7 & 6.7 & - & - & 267 \\
\hline Lwasaki $^{25}$ & 1987 & 54.2 & 19.5 & 24.3 & 2 & - & - & 251 \\
\hline Yamaki $^{26}$ & 1998 & 58 & 13.6 & 22.8 & 5.4 & 0.2 & - & 645 \\
\hline Sakthivelavan & 2014 & 63.2 & 15.8 & 21 & - & - & - & 116 \\
\hline Talalwah $^{28}$ & 2014 & 36.1 & 5.3 & 34.8 & 2.3 & - & - & 342 \\
\hline $\begin{array}{l}\text { Present } \\
\text { study }\end{array}$ & 2018 & 54.2 & 17.7 & 20.7 & 5.6 & 0.4 & 3.46 & 4948 \\
\hline
\end{tabular}

Table 5: Types of variation the internal pudendal artery (IPA) classified by Kawanishi ${ }^{29}$

\begin{tabular}{|c|c|}
\hline Types & Variation \\
\hline 1 & $\begin{array}{l}\text { The IPA originates from the anterior trunk of IIA at the level between the linea terminalis and the } \\
\text { greater sciatic foramen }\end{array}$ \\
\hline 2 & The IPA originates from the anterior trunk of the IIA at the level of the distal to greater sciatic foramen \\
\hline 3 & The IPA gives off directly from the IIA at a level proximal to the linea terminalis \\
\hline 4 & The IPA, superior and inferior gluteal artery originates from anterior trunk within $1 \mathrm{~cm}$ of each other \\
\hline 5 & The penile artery is other than the IPA, such as the obturator artery \\
\hline
\end{tabular}




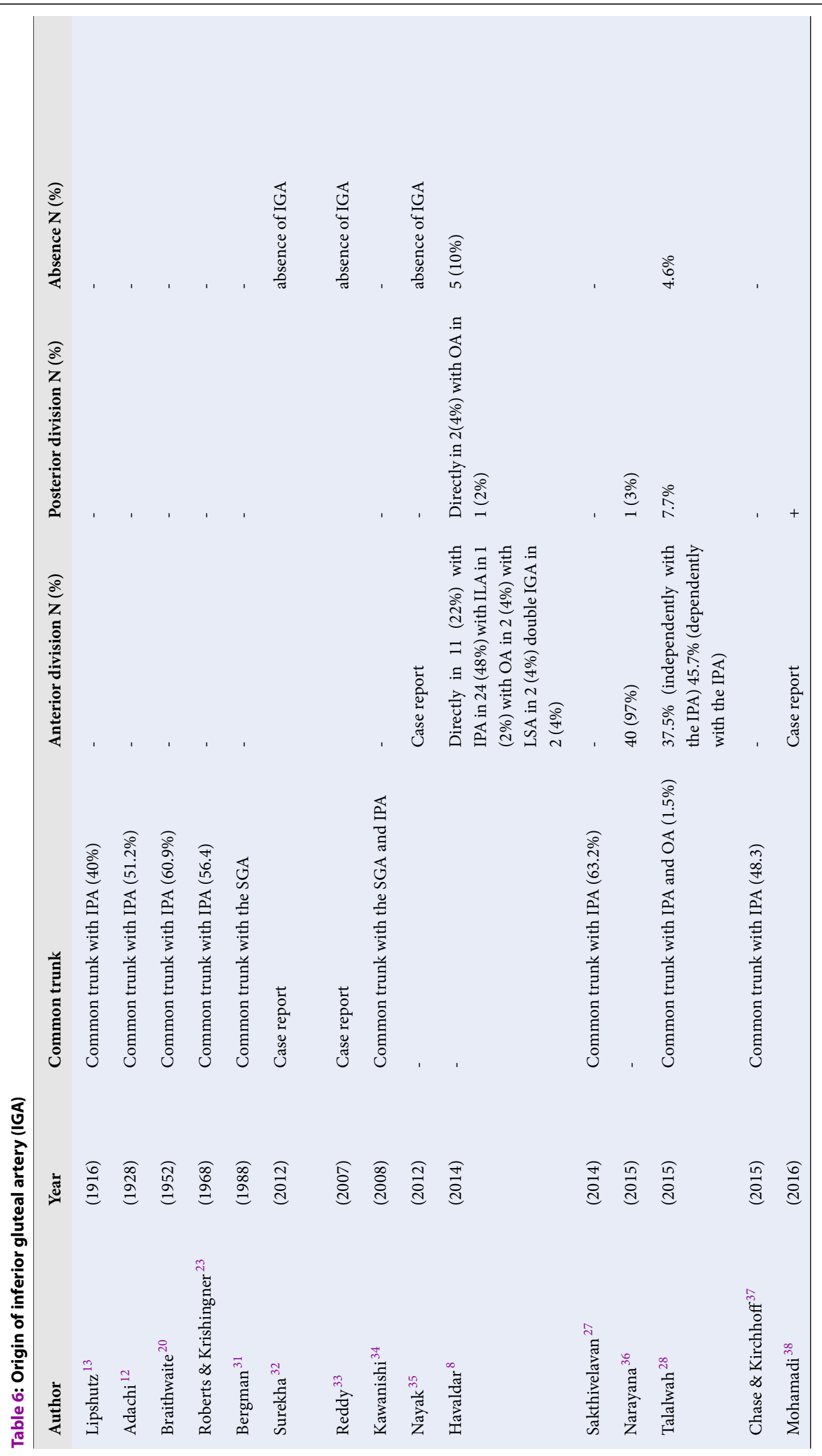



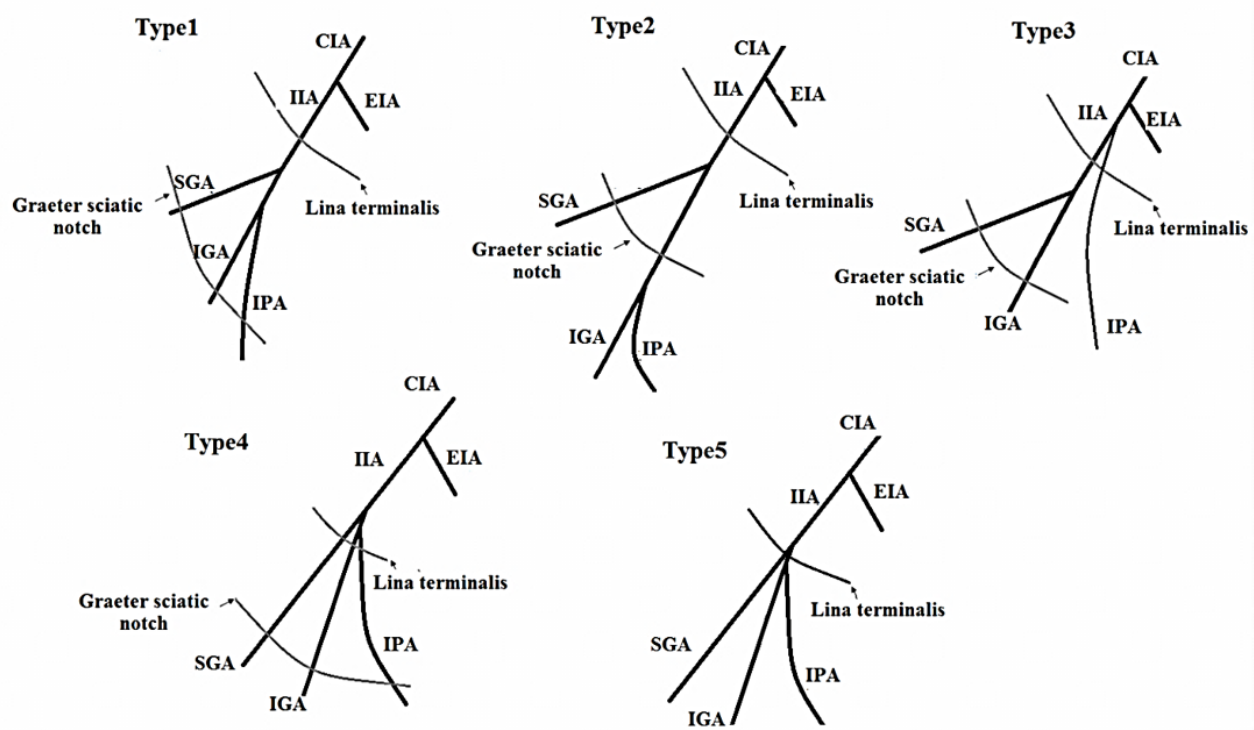

Figure 3: Types of variation the internal pudendal artery (IPA). 
Table 7: Origin of obturator artery (OA)

\begin{tabular}{|c|c|c|c|c|c|c|c|c|c|c|c|c|}
\hline \multirow{2}{*}{$\begin{array}{l}\text { Origin of } \\
\text { obturator artery }\end{array}$} & \multicolumn{12}{|c|}{ Frequencies showed by author in\% } \\
\hline & $\begin{array}{l}\text { Parsons } \\
(1897)\end{array}$ & $\begin{array}{l}\text { Pick } \\
(1942)\end{array}$ & $\begin{array}{l}\text { Braithwa } \\
(1952)\end{array}$ & $\begin{array}{l}\text { Pushpa } \\
\text { (2006) }\end{array}$ & $\begin{array}{l}\text { Kumar } \\
(2007)\end{array}$ & $\begin{array}{l}\text { Pia } \\
(2009)\end{array}$ & $\begin{array}{l}\text { Havaldar } \\
(2014)\end{array}$ & $\begin{array}{l}\text { Rajive } \\
(2015)\end{array}$ & $\begin{array}{l}\text { Narayana } \\
(2015)\end{array}$ & $\begin{array}{l}\text { Mamatha } \\
(2015)\end{array}$ & $\begin{array}{l}\text { Sonje } \\
(2016)\end{array}$ & $\begin{array}{l}\text { Goke } \\
(2016)\end{array}$ \\
\hline Ref. & 40 & 41 & 20 & 42 & 43 & 44 & 8 & 45 & 36 & 5 & 46 & 47 \\
\hline $\begin{array}{l}\text { Common trunk } \\
\text { of the IIA }\end{array}$ & - & - & - & - & - & - & - & 4 & - & - & - & - \\
\hline ILA & 4.9 & 1.8 & 3.5 & - & - & 1.04 & 10 & - & 2 & - & - & - \\
\hline $\begin{array}{l}\text { Posterior divi- } \\
\text { sion of IIA }\end{array}$ & - & - & - & - & 3.16 & 7.2 & 18 & 10 & - & 14 & 10 & - \\
\hline $\begin{array}{l}\text { Anterior } \\
\begin{array}{ll}\text { vision of } \\
\text { (normal) }\end{array} \\
\text { IIA }\end{array}$ & 68.5 & 76 & 75.9 & 100 & - & 61.4 & 40 & 54 & 64 & 66 & 67.9 & - \\
\hline SGA & - & - & - & - & - & 9.3 & - & 2 & - & - & - & - \\
\hline IPA & - & - & - & - & - & - & 8 & 2 & - & - & 10.8 & - \\
\hline $\begin{array}{l}\text { Inferior epigas- } \\
\text { tric }\end{array}$ & 25 & 21.3 & 19.5 & - & - & 14.58 & 6 & 22 & 26 & - & 2 & - \\
\hline Direct form EIA & 1.6 & 0.9 & 1.1 & - & - & 5.2 & 2 & 4 & 8 & & 5.1 & $\begin{array}{l}100 \text { (Case } \\
\text { report) }\end{array}$ \\
\hline By double origin & - & - & - & - & - & - & - & - & - & - & & - \\
\hline IGA & - & - & - & - & - & - & 6 & 2 & - & & 4.3 & - \\
\hline IVA & - & - & - & - & - & - & 4 & - & - & 8 & - & - \\
\hline MRA & - & - & - & - & - & - & 2 & - & - & - & - & - \\
\hline UA & - & - & - & - & - & - & 2 & - & - & - & - & - \\
\hline Abnormal (OA) & - & - & - & - & - & - & - & - & - & 12 & - & - \\
\hline Absent & - & - & - & - & - & - & 2 & - & - & - & - & - \\
\hline
\end{tabular}




\section{Visceral branches}

\section{Uterine artery (UtA)}

Most often, the uterine artery (UtA) is a second or third branch of the anterior division of the IIA. The UtA gives off anterior and posterior arcuate branches which have to anastomose with the ovarian artery. Current literature reportes variant origins for the UtA. These variations were associated with abnormal pregnancy outcome, injury of the artery with ligation or sectioning of the ureter.

Gomez-Jorge (2003) classified the origin of UtA in 4 types ${ }^{48,49}$ :

1. Type 1: The UtA began as the first branch (IGA) of the anterior trunk of IIA

2. Type 2: The UtA began as the second or third branch

3. Type 3: The UtA began as a trifurcation with other arteries

4. Type 4: The UtA began as the first branch of the CIA

Previous studies documented the umbilical artery (UBA) to be a continuation of the IIA. In embryos, the dorsal aorta of the lower limb divided to ventral (UBA) and dorsal (CIA) branches during the development. Then, the UBA unites with the IIA through vessels anastomosis. The UBA arise from any branch of IIA, such as the main trunk of IIA, SGA, IGA and IPA.

\section{Middle rectal arteries (MRA)}

This artery is the visceral brunch of the anterior division of the IIA which is frequently absent. The MRA also stem from the IGA and or IVA with the common trunk at the anterior division of IIA. The role of the MRA is to provide an arterial supply to the muscle of the mid and lower rectum and the extensive rectal anastomosis. Hence, the function of the MRA may be significant for the provision of collateral blood flow during intestinal embolization. Didio (1986) reported that the MRA originated from the IPA in $40 \%$ of the studied cases, IGA in $26.7 \%$ and IIA in16.8. In addition, the MRA was found in $56.7 \%$ of the specimens, bilaterally $36.7 \%$ and unilaterally $20 \%{ }^{54}$. Havaldar (2014) described the origins of MRA in 50 specimens as follows: from anterior division (4\%), IPA (64\%), IVA (6\%), OA (2\%), IGA (8\%). MRA was absent in $16 \%$ of cases. One of the complications of surgery procedures such as Hartmann's procedure, is acupuncture to the proximal rectum region. During the Hartmann, s procedure superior rectal artery is often damaged which due to atrophy of remaining rectal part $^{8}$. Naidoo (2018) reported that the MRA was not at principal for the arterial supply of the proximal rectum. However, this can assist to preserve the rectal arterial supply in the procedure of surgery ${ }^{55}$.

\section{Superior vesical artery (SVA)}

According to the anatomical textbook (Gray's Anatomy), this artery often arises from the anterior division of IIA and UBA, as well as from the OA (4.4\%), UtA (9\%) and vesicodeferential (9\%) (Table 8).

The SVA supplies the fundus of the bladder, ureter, vas deferens and testis, where it forms an anastomosis with the testicular artery. The beginning of the SVA is at the patent portion of the fetal UBA. The study of Levi and Dubreuil-Chambardel (1925) describe that the number of SVA varies from one to five (Table 9). This finding differed from that of older anatomists, who reported SVA having a single branch $\left({ }^{56,57}\right)$.

\section{Inferior vesical artery (IVA)}

The IVA commonly arises from the anterior division of IIA together with the MRA. IVA may stem from IPA, IGA or together with IPA and SGA (Table 10). According to the authors, the description of the IVA is variable between to genders. In men, it supplies the base of the bladder, prostate, seminal vesicles, vas deferens, and lower ureter. While in women, the UA with its vesical and vaginal branches vascularize upper part of the bladder $\left({ }^{1,3}\right)$.

\section{The vaginal artery (VA)}

The VA commonly arises against two or three branches that correspond to the IVA in males. They descend to the vagina and supply the vestibular bulb, vesical fundus, and adjacent part of the rectum.

\section{Posterior trunk of the IIA}

\section{Superior gluteal artery (SGA)}

The largest branch of the posterior division of the IIA is the SGA. This artery passes in the vicinity to the lumbosacral plexus and reaches the large sciatic foramen, which then passes through the foramen and out of the pelvis. In 2015, Cook defined the type of arteries according to the pathway of the SGA and its relationship with the lumbosacral trunk (LST) that include $^{58}$ :

1. Type I: The SGA was between the LST and spinal nerve S1 (67.9\%) 


\begin{tabular}{|c|c|c|c|c|c|c|}
\hline \multirow{2}{*}{$\begin{array}{l}\text { Types of } \\
\text { variation }\end{array}$} & \multicolumn{6}{|c|}{ Frequencies showed by author in \% } \\
\hline & $\begin{array}{l}\text { Pelage } \\
(1999)\end{array}$ & $\begin{array}{l}\text { Holub } \\
(2005)\end{array}$ & $\begin{array}{l}\text { Obimbo } \\
(2010)\end{array}$ & $\begin{array}{l}\text { lbulescu } \\
(2014)\end{array}$ & $\begin{array}{l}\text { Havalda } \\
(2014)\end{array}$ & $\begin{array}{l}\text { Mohamadi } \\
(2016)\end{array}$ \\
\hline Ref. & 50 & 51 & 52 & 53 & 8 & 38 \\
\hline 1 & $45 \%$ & 30.8 & $18.9 \%$ & $24 \%$ & $88 \%$ & - \\
\hline 2 & $6 \%$ & 23.4 & $70.8 \%$ & $10 \%$ & $12 \%$ & - \\
\hline 3 & $43 \%$ & 45.6 & $10.4 \%$ & $29 \%$ & - & - \\
\hline 4 & $6 \%$ & - & $0 \%$ & $37 \%$ & - & $+($ case report $)$ \\
\hline
\end{tabular}

Table 9: Origin of Superior vesical artery (SVA)

\begin{tabular}{lll}
\hline Origin of SVA & \multicolumn{2}{c}{ Author } \\
& Parson and keith (1897) & Bergman (1988) \\
Ref. & 40 & 31 \\
Hypo gastric trunk & 75.9 & - \\
Anterior division & 15.5 & - \\
IIA & 7 & - \\
MRA & 2 & - \\
Double & 2 & - \\
UtA & - & 4.4 \\
OA & - & 9 \\
vesicodeferential & - & 9 \\
\hline
\end{tabular}

2. Type II: the SGA was outside of the LST (20.5\%)

3. Type III: the SGA was between the L4 and L5 $(9.8 \%)$

4. Type IV: the SGA was between the S1 and S2 $(1.8 \%)$

Table 10: Number of Superior vesical artery

\begin{tabular}{lll}
\hline No. of SVA & Levi (1902) & \multicolumn{1}{c}{ Author } \\
& $10 \%$ & Dubreuil-Chambardel (1925) \\
One & $70 \%$ & $9 \%$ \\
Two & $12 \%$ & $74 \%$ \\
Three & $8 \%$ & $9 \%$ \\
Four & $8 \%$ & $6 \%$ \\
Five & $2 \%$ \\
\hline
\end{tabular}


Table 11: Origin of inferior vesical artery (IVA) and vaginal artery (VA)

\begin{tabular}{|c|c|c|c|c|}
\hline Author & Ref & \multicolumn{2}{|c|}{ Origin of IVA or VA } & Describe \\
\hline Bichat (1812) & 59 & & IIA and UBA & No distinction between men and women \\
\hline $\begin{array}{l}\text { Kamina } \\
(1974,2014)\end{array}$ & 60 & & IIA and UA & IVA is a male specific artery \\
\hline Drake (2015) & 60 & & UA & $\begin{array}{l}\text { IVA No distinction in women } \\
\text { The VA is branch of the UA } \\
\text { VA is the equivalent of IVA in men }\end{array}$ \\
\hline Moor (2011) & 3,60 & & & IVA is only in men \\
\hline Moses (2015) & & & & IVA is replaced in women with VA \\
\hline \multicolumn{5}{|l|}{ Bouchet (1983) } \\
\hline Schunke (2007) & 60 & & & IVA is in women \\
\hline Rouviere (2002) & 60 & & & IVA is in two sexes \\
\hline \multirow[t]{3}{*}{ Netter (1997) } & 4 & & IIA & IVA is in two sexes \\
\hline & & & & IVA is a branch of IIA \\
\hline & & & & Vaginal and uterine branch arise from IVA \\
\hline \multirow[t]{5}{*}{ Bergman (1988) } & 31 & & Anterior division (22.4\%) & It has anastomosis with UtA in $60-70 \%$ of specimen. \\
\hline & & & MRA (4\%) & The IVA is often a single branch and specific to men. \\
\hline & & & IIA $(3.5 \%)$ & vaginal artery arises from the UtA, IIA, MRA or SVA \\
\hline & & & SVA $(2 \%)$ & \\
\hline & & & Hypo gastric trunk (68.9\%) & \\
\hline \multirow[t]{7}{*}{ Havaldar (2014) } & 8 & Origin of IVA & Anterior division (42\%) & It correlate with the research \\
\hline & & & MRA $(6 \%)$ & of Bergman \\
\hline & & & IPA $(28 \%)$ & \\
\hline & & & $\mathrm{OA}(12 \%)$ & \\
\hline & & & Double (12\%) & \\
\hline & & VA & Anterior division (88\%) & \\
\hline & & & IPA $(12 \%)$ & \\
\hline
\end{tabular}


Table 12: Number of lateral sacral arteries (LSA)

\begin{tabular}{lccccc}
\hline Author & Year & \multicolumn{2}{c}{ Number of LSA } & Four \\
& & One & Two & Three & 0 \\
Tonkoff $^{61}$ & 1898 & 0 & 98 & 2 & 0 \\
Naguib $^{62}$ & 2008 & 30 & 48 & 9 & 0 \\
Bergman $^{31}$ & & 50.9 & 47.2 & 0 & 0 \\
Sadler $^{63}$ & 1990 & 55 & 45 & 0 & 1.5 \\
Sharpey $^{64}$ & 1867 & 26 & 61.5 & 11 & 0 \\
Poynter $^{65}$ & 1922 & 50 & 42.5 & 7.5 & 0.3 \\
Talalwa $^{28}$ & 2014 & 77.2 & 19.8 & 2.3 & 0 \\
Sakthivelavan $^{6 t}$ & 2014 & 32.7 & 0 & 0 & 0 \\
Havaldar $^{8}$ & 2014 & 24 & 76 & 0 & \\
\hline
\end{tabular}

Table 13: Origin of lateral sacral arteries (LSA)

\begin{tabular}{lccccc}
\hline Origin of LSA & \multicolumn{5}{c}{ Frequencies showed by author in \% $^{*}$} \\
& Talalwah $^{27}$ & Sakthivelavan $^{27}$ & Bergman $^{31}$ & Bleich $^{66}$ & Havaldar $^{8}$ \\
Posterior division & 79.1 & 97.3 & 92.6 & $5.7 \%$ & 90 \\
Anterior division & 1.0 & 32.7 & 7.4 & - & 4 \\
SGA & 16.8 & - & - & - & - \\
IGA & 5.4 & - & - & - & - \\
IPA & 0.3 & - & - & - & - \\
Persistent & 8.8 & - & - & - & - \\
sciatic artery & & - & - & 61.4 & 6 \\
Absence & 0.3 & - & - &
\end{tabular}


Table 14: Origin of lliolumbar artery (ILA)

\begin{tabular}{|c|c|c|c|c|c|c|}
\hline Author & $\begin{array}{l}\text { ILA from the } \\
\text { CIA }\end{array}$ & $\begin{array}{l}\text { ILA from the bifur- } \\
\text { cation of the CIA }\end{array}$ & ILA from the main stem of the IIA & $\begin{array}{l}\text { ILA from the point } \\
\text { of IIA bifurcation }\end{array}$ & $\begin{array}{l}\text { ILA from the } \\
\text { posterior di- } \\
\text { vision of the } \\
\text { IIA }\end{array}$ & Ref \\
\hline Chait (1968) & & & & & $\mathrm{X}$ & 67 \\
\hline $\begin{array}{l}\text { Hare and Holland } \\
(1983)\end{array}$ & & & & & $\mathrm{X}$ & 68 \\
\hline Ebraheim (1997) & $\mathrm{X} 3.7 \%$ & & X 96.3\% & & & 69 \\
\hline Chen (1999) & $\mathrm{X}$ & & $\mathrm{X}$ & & & 70 \\
\hline Mehta (2001) & & & & & $\mathrm{X}$ & 71 \\
\hline Yano (2001) & & & & & $\mathrm{X}$ & 72 \\
\hline Harrington (2001) & & & $\mathrm{X}$ & & & 73 \\
\hline Winters (2002) & & & $\mathrm{X}$ & & & 74 \\
\hline Yiming (2002) & & & $\mathrm{X}$ & & & 75 \\
\hline Elliot and Smit (2006) & & & $\mathrm{X}$ & & & 76 \\
\hline Yoon $(2004)$ & & & $\mathrm{X}$ & & $\mathrm{X}$ & 76 \\
\hline Heye (2006) & & & $\mathrm{X}(61 \%)$ & & $\mathrm{X}$ & 76 \\
\hline Kiray (2006) & $\mathrm{X}$ & & & & & 76 \\
\hline Bleich (2007) & & & $\mathrm{X}(28.3 \%)$ & & $\mathrm{X}$ & 66 \\
\hline Naguib (2008) & & & $X(50 \%)$ & $X(6 \%)$ & $\mathrm{X}(44 \%)$ & 62 \\
\hline Rusu (2010) & $8.75 \%$ & $2.5 \%$ & $52.5 \%$ & $3.75 \%$ & $32.5 \%$ & 76 \\
\hline
\end{tabular}




\begin{tabular}{ll}
\hline Table 14 continued & \\
\hline Sakthivelavan (2014) & ILA (16.4\%) \\
& LSA (19.8\%) \\
& ILA and LSA as separate branches (3.4\%) \\
& ILA and LSA as a common trunk (6.9\%) \\
& ILA as separate branch and LSA and MRA as com- \\
& mon trunk (3.4\%) \\
& Common trunk for ILA and MRA (3.4\%) \\
& LSA and MRA as separate branches (3.4\%) \\
& No branch before division (43.1\%) \\
Mamatha (2015) & $6 \%$ \\
Narayana (2015) & $2 \%$ (from OA) \\
\hline
\end{tabular}




\section{Lateral sacral arteries (LSA)}

Another branch of the posterior trunk of the IIA is the LSA, which is immediately divided into superior and inferior branches after formation. The superior branch passes dorsally to supply the structure of the sacral canal. The inferior branch passes to the ventral surface of piriformis then through the anterior sacral foramen to supply the sacral canal, skin, and muscle over the posterior surface of the sacral region. Several studies show the variation in the origin of the LSA; however, it remains unclear. The current study includes the variability of LSA and its occurrence to provide main anatomical data for radiologists, clinicians and surgeons. In another study, the LSA was found one to four arteries in specimens $\left({ }^{1,4}\right)$ (Tables 11, 12 and 13).

\section{Iliolumbar artery (ILA)}

The ILA arises from the posterior division of IIA. It runs deep to the EIA and crosses between the obturator nerve and the lumbosacral plexus. ILA then runs between the iliacus and the iliac fascia muscles and supplies muscles and bone. Harrington has reported several branches of ILA that includes: The lumbar, spinal and iliac branches ${ }^{1,3}$ (Table 14).

\section{CONCLUSION}

Identifying and reviewing the locations, orientations, and anatomical details of the IIA is essential for successful performance of endoscopic extraperitoneal inguinal hernioplasty (TEP), ligation of IIA during acute hemorrhage, ureteral injury and vein laceration. Pelvic surgeries may lead to hemorrhage if branching patterns of the IIA are incorrectly interpreted. Moreover, in women, acquiring information on the pelvic vascularization and anatomic variations is necessary for protecting perineal functionality in the case of blood vessels injury. It is important for surgeons and radiologists to have anatomical information about common variations of the uterine artery because these variations may depend on the procedures used to improve hemostasis. Failure to understand the IIA variations can lead to bleeding and thus endanger the patient's life, exclusively in the severe complications such as ligation of the external iliac artery, removing the prostate, hernia repair or uterine fibroid.

\section{COMPETING INTERESTS}

The authors declare that there is no conflict of interest regarding the contents of this article.

\section{AUTHORS' CONTRIBUTIONS}

In this study, all authors participated in the various stages of the manuscript editing and approved the final version of manuscript.

\section{ACKNOWLEDGMENTS}

Student research committee, Ilam University of Medical Sciences, Ilam, Iran, supported this review article. The authors would like to thank all individuals who have improved their manuscript with their comments.

\section{REFERENCES}

1. Williams PL, Bannister LH, Berry MM, Collins P, Dyson M, Dussek JE, et al. Gray's anatomy: the anatomical basis of medicine and surgery. Edinburgh: Churchill Livingstone; 1995.

2. SNELL RS. Clinical anatomy for students. Philadelphia: Lippincott, William \& Wilkins,; 2000. p. 292-293.

3. Netter FH. Anatomie medicale: aspects fondamentaux et applications cliniques. Paris: De Broeck; 1997. p. 349-355.

4. Moore KL, Dalley AF. anatomie medicale: aspects fondamentaux et applications cliniques. 3rd ed. Paris: De Broeck; 2011.

5. Mamatha H, Hemalatha B, Vinodini P, Souza S. Anatomical Study on the Variations in the Branching Pattern of Internal IIiac Artery. Indian J Surg . 2015;77(I 2):S248-S252. Available from: $10.1007 /$ s12262-012-0785-0.

6. Jastchinski S. Die tyischen verzweigsform der arteria hypogastrica. Int Mschr Anat Physiol. 1891;8:111-27.

7. Moher D, Liberati A, Tetzlaff J, Altman DG, Group $P_{i}$ Group P. Preferred reporting items for systematic reviews and meta-analyses: the PRISMA statement. PLoS Med. 2009;6(7):e1000097. 19621072. Available from: 10.1371/journal.pmed.1000097.

8. Havaldar PP, Taz S, Angadi AV, Saheb SH. Study of posterior division of internal iliac artery. Int J Anat Res. 2014;2(2):375-9.

9. Naveen NS. Morphological Analysis of the Human Internal IIiac Artery in South Indian Population. Online J Health Allied Sci. 2011;10(1):1-4.

10. Fatu C, Puişoru M, Fatu IC. Morphometry of the internal iliac artery in different ethnic groups. Ann Anat. 2006;188(6):5416. 17140147. Available from: 10.1016/j.aanat.2006.05.016.

11. Hawaldar PP, Taz S, Angadi AV, Saheb SH. Morphological study of obturator artery. Int J Anat Res. 2014;2(2):354-7.

12. Adachi B. Das Arteriensystem der Japaner. Kyoto: Maruzen; 2014.

13. Lipshutz B. A Composite Study of the Hypogastric Artery and its Branches. Ann Surg. 1918;67(5):584-608. 17863918. Available from: 10.1097/00000658-191805000-00012.

14. Tsukamoto N. Studies on the arterial system in pelvic cavity of Japanese. Acta Mat Nippon. 1929;2:830-52.

15. Miyaji K, die AU. hypogastrica. Arbeit Mat Institut Kanazawa. 1935;20:85-93.

16. Arai S. The distribution pattern of the hypogastric artery in Japanese. Acta Anat Nippon. 1936;9:81.

17. Hoshiai H. Anatomical study on the pelvic arteries in Japanese fetus. Acta Mat Nippon. 1938;11:61-72.

18. Ashley FL, Anson BJ. The hypogastric artery in American whites and negroes. Am J Phys Anthropol. 1941;28(4):381-95. Available from: 10.1002/ajpa.1330280404.

19. Suzuki $H$. The mode of branching of the internal iliac artery in Japanese. Jikeikai Ikadaigaku kaibougaku Kyoshitsu Gyosekishu . 1951;5:1-49.

20. Braitwaite JL. Variations in origin of the parietal branches of the internal iliac artery. J Anat. 1952;86(4):423-30. 12999644.

21. Yasukawa S. An Anatomical study on the hypogastric artery in Japanese. Jikeikai Ikadaigaku kaibougaku Kyoshitsu Gyosekishu. 1954;12:1-43. 
22. Fisher W. Anatomisch-rontgenologische Untersuchungen uber die Verteilung and Anastomosenbildung der viszeralen and parietalen weiblichen Beckenarterien. Geburtsh Gynaek. 1959;154:321-40.

23. Roberts WH, Krishingner GL. Comparative study of human internal iliac artery based on Adachi classification. Anat Rec. 1967;158(2):191-6. 6034641. Available from: 10.1002/ar. 1091580208.

24. Morita S, Kato S, Sugawara E. Corrosions anatomical studies on the arterial system of the Japanese fetus. VIII. The common iliac arteries and the branches of the internal iliac artery. Acta Mat Nippon. 1974;49:79.

25. Iwasaki Y, Shoumura S, Ishizaki N, Emura S, Yamahira T, Ito M, et al. [The anatomical study on the branches of the internal iliac artery comparison of the findings with Adachi's classification]. Kaibogaku Zasshi. 1987;62(6):640-5. 3451658.

26. Yamaki K, Saga T, Doi Y, Aida K, Yoshizuka M. A statistical study of the branching of the human internal iliac artery. Kurume Med J. 1998;45(4):333-40. 9914720. Available from: 10.2739/ kurumemedj.45.333.

27. Sakthivelavan S, Aristotle S, Sivanandan A, Sendiladibban S, Jebakani CF. Variability in the branching pattern of the internal iliac artery in Indian population and its clinical importance. Anat Res Int. 2014;2014:597103. 25580296. Available from: $10.1155 / 2014 / 597103$.

28. Talalwah WA, Soames R. Internal iliac artery classification and its clinical significance. Rev Arg Anat Clin. 2014;6:63e71.

29. Kawanishi Y, Muguruma H, Sugiyama H, Kagawa J, Tanimoto S, Yamanaka $\mathrm{M}$, et al. Variations of the internal pudendal artery as a congenital contributing factor to age at onset of erectile dysfunction in Japanese. bjuinter national. 2007;101:581-586.

30. Gabrielli C, Olave E, Sarmento A, Mizusaki C, Prates JC. Abnormal extrapelvic course of the inferior gluteal artery. Surg Radiol Anat. 1997;19(3):139-42. 9381313. Available from: 10.1007/BF01627962.

31. Bergman RA, Thomson SA, Afifi AK, Saadesh FA. Compendium of Human Anatomic Variations. Munich: Urban \& Schwarzenberg, Ba Itimore; 1988.

32. Surekha $D, A b h i n i t h a P$. Total replacement of inferior gluteal artery by a branch of superior gluteal artery. int J Anat Var (IJAV). 2012;5:85-86

33. Reddy S, Vollala VR, Rao M. Absence of inferior gluteal artery: a rare observation. Int J Morphol. 2007;25(1):95-8. Available from: 10.4067/S0717-95022007000100012.

34. Kayalvizhi I, Narayan RK, Kumar P. Anatomical variations of testicular artery: a review. Folia Morphol (Warsz). 2017;76(4):541-50. 28394009. Available from: 10.5603/FM. a2017.0035.

35. Nayak SB, Sirasanagandla SR, Pamidi N, Jetti R. Variations in the branching pattern of the internal iliac artery in an adult male: a case report. Revista Argentina De Anatomia Clinica. 2012;4(1):25-8.

36. Narayana A, Padmini MA. Study of Anamolous Origin Of Gluteal Arteries. International Journal Of Current Pharmaceutical. 2015;7(6):14-6.

37. Chase J, Kirchhoff C. Variation in the Branching Pattern of the Internal Iliac Artery; 2016.

38. Mohamadi $Y$, Toolee H, Hassanzadeh G. Bilateral Variation of Internal Iliac Artery: A Case Study. Anatomical Sciences. 2016;13(3):197-9.

39. Deeba S, Purkayastha S, Darzi A, Zacharakis E. Obturator hernias: A review of the laparoscopic approach. J Minim Access Surg. 2011;7(4):201-204.

40. Parsons FG, Keith A. Sixth Annual Report of the Committee of Collective Investigation of the Anatomical Society of Great Britain and Ireland, 1895-96. J Anat Physiol. 1896;31(Pt 1):3144. 17232229.

41. Pick JW, Barry J, Anson BJ, Ashley FL. The origin of obturator artery - a study of 640 body halves. Am J Anat. 1942;70(2):31744. Available from: 10.1002/aja.1000700206.

42. Pushpa MS, Kulkarni R, Sheshgiri C, Kulkarni RN. Variations in the branching pattern of internal iliac artery case report. J
Anat Soc India. 2006;55:83.

43. Kumar D, Rath $G$. Anomalous origin of obturator artery from the internal iliac artery. Int J Morphol. 2007;25(3):639-41. Available from: 10.4067/S0717-95022007000300028.

44. Pai MM, Krishnamurthy A, Prabhu LV, Pai MV, Kumar SA, Hadimani GA. Variability in the origin of the obturator artery. Clinics (S\{ã\}o Paulo). 2009;64(9):897-901. 19759884. Available from: 10.1590/S1807-59322009000900011.

45. Rajive AV, Pillay M. A Study of Variations in the Origin of Obturator Artery and its Clinical Significance. J Clin Diagn Res. 2015;9(8):12-5. 26435935.

46. Sonje PD, Vatsalaswamy P. Study of Variations in the Origin of Obturator Artery. Indian J Vasc Endovasc Surg. 2016;3(4):1315. Available from: 10.4103/0972-0820.191494.

47. Goke K, Pires LA, Leite TF, Chagas CA. Rare origin of the obturator artery from the external iliac artery with two obturator veins. J Vasc Bras. 2016;15(3):250-3. 29930598. Available from: 10.1590/1677-5449.005116.

48. Razavi MK, Wolanske KA, Hwang GL, Sze DY, Kee ST, Dake MD. Angiographic classification of ovarian artery-to-uterine artery anastomoses: initial observations in uterine fibroid embolization. Radiology. 2002;224(3):707-12. 12202703. Available from: 10.1148/radiol.2243011513.

49. Gomez-Jorge J, Keyoung A, Levy EB, Spies JB. Uterine artery anatomy relevant to uterine leiomyomata embolization. Cardiovasc Intervent Radiol. 2003;26(6):522-7. 15061175. Available from: $10.1007 / \mathrm{s} 00270-003-2652-7$.

50. Pelage JP, Dref OL, Soyer $P$, Jacob D, Kardache $M$, Dahan $H_{\text {, }}$ et al. Arterial anatomy of the female genital tract: variations and relevance to transcatheter embolization of the uterus. AJR Am J Roentgenol. 1999;172(4):989-94. 10587133. Available from: 10.2214/ajr.172.4.10587133.

51. Holub Z, Lukac J, Kliment L, Urbanek S. Variability of the origin of the uterine artery: laparoscopic surgical observation. J Obstet Gynaecol Res. 2005;31(2):158-63. 15771643. Available from: 10.1111/j.1341-8076.2005.00264.x.

52. Obimbo MM, Ogeng'o JA, Saidi H. Variant anatomy of the uterine artery in a Kenyan population. Int J Gynaecol Obstet. 2010;111(1):49-52. 20579998. Available from: 10.1016/j.ijgo. 2010.04.033.

53. Albulescu D, Constantin C, Constantin C. Uterine artery emerging variants - angiographic aspects. Curr Health Sci J. 2014;40(3):214-6. 25729609.

54. DiDio L, Franco C, Schemainda R, Bezerra AJC. Morphology of the middle rectal arteries. Surgical and Radiologic Anatomy. 1986;8(4):229-236.

55. Naidoo N, Lazarus L, Singh B, Satyapal K. Clinical relevance of the arterial supply to the proximal rectum. Eur J Anat. 2018;22(1):67-73.

56. Dubreuil-Chambardel L. Variations in the origin of obturator artery coming from the external iliac artery. Paris: Masson; 1925.

57. Levi G. Observations sur les variations de arteries iliaques (Observations on changes in iliac arteries). Arch Ital Biol. 1902;37:489.

58. Cook AM, Dyet JF. Percutaneous angioplasty of the superior gluteal artery in the treatment of buttock claudication. Clin Radiol. 1990;41(1):63-5. 2137056. Available from: 10.1016/ S0009-9260(05)80937-7.

59. Bichat $X$. Traité d'anatomie descriptive. Brosson Tome 1812;IV:294-306.

60. de Treigny OM, Roumiguie M, Deudon R, de Bonnecaze G, Carfagna L, Chaynes P, et al. Anatomical study of the inferior vesical artery: is it specific to the male sex? Surg Radiol Anat. 2017;39(9):961-5. 28229186. Available from: 10.1007/s00276-017-1828-9.

61. Tonkoff W. Die Arterien der Intervertebralganglion und der Cerebrospinalnerven des Menschen. Int Mschr Anat Physiol. 1898;15:353-401.

62. Naguib NN, Nour-Eldin NE, Hammerstingl RM, Lehnert $T$, Floeter J, Zangos S, et al. Three-dimensional reconstructed 
contrast-enhanced MR angiography for internal iliac artery branch visualization before uterine artery embolization. J Vasc Interv Radiol. 2008;19(11):1569-75. 18824376. Available from: 10.1016/j.jvir.2008.08.012.

63. Sadler T. Langman's Medical Embryology. London, UK: Williams \&amp; Wilkins; 1990

64. Sharpey W, Thomson A, Cleland J. Quain's Elements of Anatomy. London, UK: Longmans, Green and Co; 1867.

65. Poynter $C$. Congenital anomalies of the arteries and veins of the human body of man with bibliography. University Studies of the University of Nebraska. 1922;9(1):1-106.

66. Bleich AT, Rahn DD, Wieslander CK, Wai CY, Roshanravan SM, Corton MM. Posterior division of the internal iliac artery: anatomic variations and clinical applications. Am J Obstet Gynecol. 2007;197(6). 18060970. Available from: 10.1016/j.ajog. 2007.08.063.

67. Chait A, Moltz A, Nelson JH. The collateral arterial circulation in the pelvis. An angiographic study. Am J Roentgenol Radium Ther Nucl Med. 1968;102(2):392-400. 5635691. Available from: 10.2214/ajr.102.2.392.

68. Hare WS, Holland CJ. Paresis following internal iliac artery embolization. Radiology. 1983;146(1):47-51. 6849068. Available from: 10.1148/radiology.146.1.6849068.

69. Ebraheim NA, Lu J, Biyani A, Yang H. Anatomic considerations of the principal nutrient foramen and artery on internal surface of the ilium. Surg Radiol Anat. 1997;19(4):237-9. 9381329. Available from: 10.1007/BF01627864.

70. Chen RS, Liu YX, Liu CB, Hu YS, Xu DC, Zhong SZ, et al. Anatomic basis of iliac crest flap pedicled on the iliolumbar artery. Surg Radiol Anat. 1999;21(2):103-7. 10399209. Available from: 10.1007/s00276-999-0103-0.

71. Mehta M, Veith FJ, Ohki T, Cynamon J, Goldstein K, Suggs WD, et al. Unilateral and bilateral hypogastric artery interruption during aortoiliac aneurysm repair in 154 patients: a relatively innocuous procedure. J Vasc Surg. 2001;33(2):27-32. 11174809. Available from: 10.1067/mva.2001.111678.

72. Yano OJ, Morrissey N, Eisen L, Faries PL, Soundararajan K, Wan $S$, et al. Intentional internal iliac artery occlusion to facilitate endovascular repair of aortoiliac aneurysms. J Vasc Surg. 2001;34(2):204-11. 11496269. Available from: 10.1067/mva 2001.115380.

73. Harrington JF. Far lateral disc excision at L5-S1 complicated by iliolumbar artery incursion: case report. Neurosurgery. 2001;48(6):1377-9. 11383746.

74. Winters HA, van Harten SM, van Royen BJ. The iliolumbar artery as the nutrient pedicle for an iliac crest graft: a new technique in reconstruction of the lumbar spine. Plast Reconstr Surg. 2002;109(1):249-52. 11786821. Available from: 10.1097/00006534-200201000-00039.

75. Yiming $A$, Baqué $P$, Rahili $A$, Mayer J, Braccini $A L$, Fontaine $A$, et al. Anatomical study of the blood supply of the coxal bone: radiological and clinical application. Surg Radiol Anat. 2002;24(2):81-6. 12197024. Available from: 10.1007/s00276$002-0029-2$

76. Rusu MC, Cergan R, Motoc AG, Folescu R, Pop E. Anatomical considerations on the corona mortis. Surg Radiol Anat. 2010;32(1):17-24. 19636491. Available from: 10.1007/s00276009-0534-7. 